\title{
mssaico
}

\section{Ditadura civil-}

militar no Brasil e a ordem de gênero: masculinidades e feminilidades vigiadas

Natanael de Freitas Silva ${ }^{1}$

\section{Brazil civil-military dictatorship and the gender order: masculinity and femininity watched}




\section{Resumo:}

O objetivo deste texto é refletir sobre algumas práticas censórias em torno de determinadas performances de gênero consideradas subversivas pelos defensores da "moral e dos bons costumes" durante o período da ditadura civil-militar brasileira. E para isso, apresento uma breve discussão historiográfica em torno da questão de gênero e sexualidade na historiografia sobre esse período, em seguida, menciono alguns exemplos dessas práticas e, por fim, concluo que as noções de masculinidade e feminilidade são constructos social e culturalmente forjados, rizomáticos, relacionais, interdependentes e de múltipla definição. Por isso, o caráter histórico, datado e político do gênero.

Palavras-chave: Ditadura, Gênero, Sexualidade, Performance, Masculinidade, Feminilidade.

\section{Abstract:}

The purpose of this paper is to reflect on some censorship practices around certain gender's performances considered subversive by the advocates of "morals and good customs" during the period of the Brazilian civil-military dictatorship. And for that, we present a brief historiographical discussion around the issue of gender and sexuality in the historiography of this period, then we mention some examples of these practices, and finally we conclude that masculinity and femininity notions are social constructs and culturally forged, rhizomatic, relational, interdependent and multiple definition. Therefore, the historical character, dated and political genre.

Keywords: Dictatorship, Genre, Sexuality, Performance, Masculinities, Femininities. 
Passados 52 anos do golpe militar, instaurado em 31 de março de 1964, ainda é necessária uma reflexão mais acurada sobre a repressão e censura praticada sobre homens e mulheres que não se adequavam a ordem de gênero vigente à época, principalmente a relação entre ditadura e homossexualidade, como sugere James Green (2014). Assim sendo, o objetivo deste texto é refletir sobre algumas práticas censórias em torno de determinadas performances de gênero consideradas subversivas pelos defensores da "moral e dos bons costumes" durante o período da ditadura civil-militar brasileira.

Começo esse percurso esclarecendo algumas posições e escolhas que possibilitam a presente reflexão. Primeiramente, opto pela denominação, ditadura civil-militar. 0 historiador Carlos Fico (2013) defende que o golpe de 1964 foi civil-militar, pois contou com a participação de agentes civis como Carlos Lacerda, Magalhães Pinto, etc. Consequentemente, o que se seguiu foi um governo estritamente militar, pois os civis foram afastados dos possíveis postos de comando como Carlos Lacerda e Adhemar de Barros. Deste modo, para o período de 1964-1985, o autor prefere a designação de ditadura militar. No entanto, o historiador Daniel Aarão Reis (2014) sugere que a participação de amplos setores organizados da sociedade civil possibilitou o golpe, a implementação e manutenção da ditadura até 1988, pois alguns se beneficiaram das políticas repressivas do período, ressaltando ainda a ambiguidade e ambivalência presentes em diferentes grupos como: intelectuais, músicos, cinema e agentes da luta armada. Entre resistências e consentimentos, Reis sugere que a ditadura foi civil-militar. Assim, para o autor, a ditadura

Não foi um raio que desceu de um céu sem nuvens [ela] resultou de uma conjunção complexa de condições, de processos e de ações, cuja compreensão permite elucidar o que deixou surpresos e perplexos os contemporâneos, vencidos e vencedores (AARÃO REIS, 2014, p. 18).

Isso nos permite entender que a trama histórica do nosso passado recente é muito mais complexa e arenosa não cabendo em esquemas simplificadores e maniqueístas de interpretação e análise da realidade como as noções de direita-esquerda, vítima-algoz, repressão-resistência (FICO, 2013a). Por isso, opto pela designação ditadura civil-militar, por entender que as práticas de censura foram em grande medida incitadas por indivíduos da sociedade civil junto às instâncias repressivas como a Divisão de Censura de Diversões Públicas (DCDP). Não quero com isso cair numa discussão nominalista, no sentido, como aponta Carlos Fico, "de acreditar que chegar a um nome, ou um conceito defina a natureza dos eventos" (FICO, 2013, p. 469). Todavia, entendo que tal designação é uma escolha política, na medida em que acentua e denuncia a participação e colaboração de setores da sociedade civil em torno da manutenção de uma histórica ordem de gênero fundamentada na heterossexualidade compulsória e na marginalização e exclusão das chamadas "minorias sexuais".

Em segundo lugar, parto da ideia de que o discurso historiográfico "não é reflexo de uma suposta base material das relações sociais de produção" (RAGO, 2006, p. 20), mas é participe e instituinte daquilo que chamamos de "real", logo, como aponta o historiador 
Albuquerque Júnior (2007, p. 61), é preciso considerar "o lugar histórico e social de onde [se] fala, e o lugar institucional onde o saber histórico se produz", ou seja, as históricas condições de possibilidades (políticas, sociais, culturais, institucionais, etc.) que nos permite dizer certas coisas e não outras (PROST, 2008). O próprio reconhecimento de que a historiografia tradicionalmente é androcêntrica (é a tendência a excluir tudo que se refere às mulheres ou possa ser associado a elas) e heterossexista (é o pressuposto de que todos os indivíduos são heterossexuais) é também um dos modos de tensionar o campo de produção acadêmico, pois se "a história é uma maneira pela qual as pessoas criam, em parte, suas identidades" (JENKINS, 2001, p. 42), cabe problematizar os usos que são feitos do passado e indagar: qual tipo de discurso se quer elaborar? Um discurso hegemônico, mantenedor da heteronorma ou um discurso de resistência, que produza clivagens, fraturas nessa imagem romantizada e polarizada do nosso passado recente?

Com efeito, entendo que é preciso desconfiar das narrativas produzidas sobre esse conturbado período da nossa história recente que muitas vezes silencia e/ou e pormenoriza as questões relacionadas ao gênero e a sexualidade, como apresento no próximo tópico. É reconhecer e não esquecer que o nosso conhecimento é perspectivista, parcial e lacunar, porquanto:

As histórias são escritas do ponto de vista dos homens, mergulhados em seu cotidiano, pressentindo que fazem parte de algo mais grandioso, que são peças em uma engrenagem social complexa, problemática, conflitiva, de que só se pode divisar contornos parciais, de que só se pode conhecer verdades interessadas e relativas a tempos, lugares e contextos (ALBUQUERQUE JÚNIOR, 2007, p. 72).

No mais, se entendermos que a História "é como um labirinto de corredores e portas contíguas" (ALBUQUERQUE JÚNIOR, 2007, p. 73), cabe a nós traçarmos outros mapas, multiplicar as narrativas que nos leve a outras direções e (des) caminhos, que tentem em alguma medida lançar luz sobre acontecimentos da vida vivida e que tenham como protagonistas aqueles e aquelas que foram excluídos dessa História.

\section{Gênero, sexualidade e ditadura}

Atualmente podemos mapear uma vasta, significativa e pujante produção bibliográfica no campo das Ciências Sociais e na Historiografia sobre o período da ditadura civil-militar no Brasil. Apesar disso, podemos observar o predomínio de determinados temas como o Golpe de 1964 (DREIFUSS, 1981; FICO, 2004; 2014; ZACHARIADHES, 2015; ALONSO; DOLHNIKOFF, 2015), a luta armada (JUNIOR, 2004; SALES, 2007; 2015) e a denominada resistência democrática (AQUINO, 1999; NAPOLITANO, 2011; RIDENTI, 2004; 2014). O que segundo o historiador Douglas Marcelino, é sintomático de um certo reducionismo das interpretações ao campo político e econômico da ditadura civil-militar, que acaba por 
cristalizar e sedimentar uma memória circunscrita à dimensão política do período. Nas palavras do autor:

\begin{abstract}
A memória construída sobre os anos da ditadura, de modo geral, tende a ressaltar somente a dimensão política da censura que existia no período. $\mathrm{Na}$ verdade, a época é lida, como um todo, sobretudo a partir da chave política. Questões como a sexualidade e outras relacionadas ao plano comportamental, quando mencionadas, são tomadas apenas como epifenômenos de uma variante política fundamental. Assim, a história do Brasil entre 1964 e 85 tem sido reduzida a história política da ditadura militar (MARCELINO, 2011, p. 22, grifo meu).
\end{abstract}

Contudo, Carlos Fico sugere e reconhece que para além desses temas priorizados pela historiografia é preciso investigar questões relacionadas ao cotidiano, à vida privada, às relações interpessoais e o que ele denomina de "pessoas comuns", como funcionários públicos (FICO, 2012). É também focalizar as chamadas "experiências criativas", como o surgimento e as práticas artísticas do grupo teatral Dzi Croquettes, do cantor Ney Matogrosso e do grupo Secos e Molhados que com uma estética ambígua ajudaram a desestabilizar as posições e atribuições normativas do que era entendido e percebido socialmente como masculino e feminino.

Ao analisar a complexa relação entre ditadura e homossexualidades, o historiador James Green reconhece que apesar do esforço analítico e da "profusão de reflexões nos últimos anos sobre o tema" (GREEN; QUINALHA, 2014, p. 18), ainda existe uma "ausência de produção acadêmica mais profunda que se mostre capaz de analisar, com o devido cuidado, as questões relacionadas às sexualidades dissidentes e suas interações com as mudanças que marcaram o regime de 1964" (Idem:19). E nesse sentido, o autor percebe que os trabalhos que tem o tema da sexualidade como objeto de análise, geralmente ignoram a "sua relativa autonomia dos processos políticos mais gerais" ou discute-o "como se estivesse completamente desconectado da história do período" (Idem:19), consequentemente, ambos os pressupostos acarretam prejuízos para analisar as complexas relações e mediações das sexualidades com a dinâmica do poder.

E nesse sentido, Green pergunta:

Quais foram os efeitos da ditadura no cotidiano de mulheres que amavam outras mulheres, de homens que desejavam ouros corpos masculinos ou mulheres e homens que se recusaram a reproduzir as noções e o comportamento hegemônico de gênero? (GREEN; QUINALHA, 2014, p. 19).

Em vista disso, é preciso destacar que os anos 1960/70 foram testemunhas de uma mudança de paradigma no Ocidente. A descrença nos ideais revolucionários, nas instituições, a liberalização sexual, mudanças nos códigos de vestuário, forjando o chamado estilo unissex, o uso de drogas e o surgimento da pílula anticoncepcional, desconectando o sexo da reprodução, tudo isso influenciou as mentes e corações de grande parte dos jovens daquela 
geração. Para o sociólogo Renato Ortiz, esse período pode ser considerado:

Um momento de liberalização dos costumes [como] o consumo de drogas, a liberdade sexual, a emancipação feminina [que] não eram simples epifenômenos que pudessem ser administrados por uma determinada concepção de mundo conservadora (ORTIZ, 2014, p. 122-123).

Ao analisar a constituição do movimento homossexual brasileiro, os antropólogos Júlio Simões e Regina Facchini (2009) identificam o processo de politização das identidades sexuais e de gênero que tinha como mote de sua atuação política o seguinte pressuposto: o pessoal é político ${ }^{1}$. Questionando a moralidade conservadora quanto aos costumes, afetos e desejos, os chamados "movimentos identitários", como o movimento negro, movimento gay e lésbico e principalmente as feministas, "avançaram a crítica questionando a figura do sujeito unitário, racional, masculino que se colocava como representante de toda a humanidade" (RAGO, 1998, p. 91).

Cabe salientar que o movimento feminista no Brasil eclodiu nos anos 1970, muito marcado pelo autoritarismo vigente no país, inclusive com a participação das mulheres na luta $\operatorname{armada}^{2}$ e pela conjuntura internacional como a declaração da ONU do ano internacional da Mulher, em 1975. Desta maneira, para a historiadora Margareth Rago, o feminismo desnaturalizou a categoria 'homem' como sujeito universal e evidenciou as relações de poder entre os gêneros alicerçados no dimorfismo sexual, percebendo "que as subjetividades são históricas e não naturais, que os sujeitos estão nos pontos de chegada e não de partida como acreditávamos então" (RAGO, 1998, p. 91). O que essa perspectiva, denominada de pós-estruturalista, coloca em evidencia é que os sujeitos de gênero não são anteriores ao discurso, mas, produzidos por uma complexa rede de signos, atos, discursos, táticas, práticas e estratégias que sedimentam e naturalizam uma visão binária e estável do gênero (BUTLER, 2013). Como sugere autora Rosa Fischer, "analisar discursos significa em primeiro lugar não ficar no nível apenas das palavras, ou apenas das coisas; muito menos, buscar a bruta e fácil equivalência de palavras e coisas" (FISCHER, 2012, p. 137), mas é procurar "não o que estaria escamoteado, mas os modos de se fazer verem certas coisas num determinado tempo" (Idem, p. 138).

Para a historiadora Angélica Müller o ano de 1968 representa o "início da problematização da identidade masculina, um período de redefinição para os papéis desempenhados pelas mulheres e de gestação do feminismo e do movimento gay no país" (2013, p. 300), assim como o início da chamada revolução sexual e cultural e a efervescência da contracultura (SILVA, 2012) no país. Com uma percepção similar, o historiador Jurandir

\footnotetext{
${ }^{1}$ Slogan atribuído à jornalista e ativista norte-americana, Carol Hanisch, ícone do feminismo radical. Publicou em 1969 um ensaio com o título, The Personal is Political. Disponível em:

<https://we.riseup.net/assets/190219/O+Pessoal\%2B\%C3\%A9\%2BPol\%C3\%ADtico.pdf>. Acesso em: 1 jul. 2016.

${ }^{2}$ SARTI, Cynthia A. O feminismo brasileiro desde os anos 1970: revisitando uma trajetória. Estudos Feministas, Florianópolis, 12(2): p. 35-50, maio-agosto, 2004.
} 
Malerba reconhece que a "fé no progresso e na civilização do mundo moderno" (2009, p. 20) foi questionada desde os anos 1960, fomentando as chamadas "revoltas antissistêmicas" como Maio de 68 na França e Stonewall em Nova York (1969), etc.

Rago também nos lembra que a entrada maciça das mulheres no campo universitário, não só como estudantes, mas como produtoras de conhecimento, de certa forma provocou uma "feminização do espaço acadêmico", questionando e desestabilizando uma produção científica masculina e heterossexista. Deste modo, elas não só reivindicaram seu lugar na História, como demandaram novos temas e novas abordagens. O que era considerado como característico do (s) mundo(s) feminino(s) ganhou visibilidade no relato histórico. "Histórias da vida privada, da maternidade, do aborto, do amor, da prostituição, da infância e da família, das bruxas e loucas, das fazendeiras, empresárias, enfermeiras" (RAGO, 1998 , p. 90). Consequentemente, novos mundos foram descortinados, novas práticas problematizadas e novas interpretações forjadas. Indo além da inclusão das mulheres no discurso histórico, se tratava de "encontrar as categorias adequadas para conhecer os mundos femininos, para falar das práticas das mulheres no passado e no presente e para propor novas possíveis interpretações inimagináveis na ótica masculina" (RAGO, 1998, p. 92).

A historiadora Maria Izilda Matos sugere que o gênero, como categoria de análise, além de reivindicar para si um território específico, "em face da insuficiência dos corpos teóricos existentes para explicar a persistência da desigualdade entre homens e mulheres" (1998, p. 69), possibilitou novas questões, novas temporalidades, ampliou o conhecimento do objeto histórico e diversificou a documentação. Nas suas palavras:

Os estudos de gênero contribuíram para a ampliação do objeto de
conhecimento histórico, levando a descoberta de temporalidades
heterogêneas, rítmos desconexos, tempos fragmentados e
descontinuidades, descortinando o tempo imutável e repetitivo ligado aos
hábitos, mas também o tempo criador, dinâmico e das inovações,
focalizando o relativo, a multiplicidade de durações que convivem entre si
urdidas na trama histórica (MATOS, 1998, p. 71).

Por isso, entendo que falar de e do gênero não é mais sinônimo de "mulher" (PEDRO, 2011), como se fez acreditar até os anos 1990, porém é uma das possiblidades de pensar, refletir, evidenciar e problematizar os históricos processos de produção de masculinidades e feminilidades numa dada sociedade. É também um dos modos de problematizar, analisar e compreender como as narrativas e interpretações sobre o período da ditadura ainda incidem num modo androcêntrico de narrar os fatos, excluindo ou dando pouca atenção às relações de gênero e as sexualidades (WELZER-LANG, 2004, p. 112). Assim, entendo que reconhecer o pressuposto heteronormativo ${ }^{3}$ que incide na escrita e no olhar sobre o passado é um caminho para desconstruir as "oposições binárias que hierarquizam

\footnotetext{
3 Segundo Miskolci (2012, p. 43-44) "constitui-se na ordem sexual do presente, fundada no modelo heterossexual, familiar e reprodutivo. Ela se impõe por meio de violências simbólicas e físicas dirigidas principalmente a quem rompe normas de gênero".
} 
razão e emoção, público e privado, masculino e feminino, heterossexualidade e homossexualidade" (RAGO, 2013, p. 27). Da mesma forma, um estudo que parte da perspectiva de gênero, investigando os processos históricos de subalternização, também é um dos modos de denunciar e evidenciar as hierarquias e desigualdades entre os sujeitos alicerçados no dimorfismo sexual. Assim, penso que não nos cabe mais ignorar essa dimensão das relações sociais pautadas no gênero em nossas reflexões.

Ao analisar a trajetória de algumas mulheres feministas e militantes de esquerda na época da ditadura, Margaret Rago vai dizer que recorrentemente a história da ditadura militar é uma história masculina ${ }^{4}$. Ela afirma que com o fim da ditadura civil-militar no país, a maioria das produções em torno da memória, dos testemunhos e das autobiografias "foram produzidos por militantes do sexo masculino, embora muitas mulheres tivessem tido uma atuação de destaque nos grupos políticos "revolucionários" e na resistência conta o regime" (RAGO, 2013, p. 62). Dessa maneira, a autora localiza os poucos trabalhos que destacam as histórias de algumas mulheres como a obra Memórias das mulheres do exílio (1980), que reuniu o depoimento de exiladas políticas, colhidos pela socióloga e feminista brasileira, Albertina de Oliveira Costa. E o trabalho autobiográfico No corpo e na alma (2002), da expresa política Derlei Catarina de Luca, "no qual apresenta depoimentos contundentes sobe a tortura física e psicológica, além de críticas radicais ao machismo da esquerda" (RAGO, 2013, p. 62).

Também podemos acrescentar a essa lista ${ }^{5}$ a obra Da guerrilha à imprensa feminista (2013) escrita a quatro mãos por Amelinha Teles e Rosalina Leite, com ênfase na produção de dois jornais feministas da época o Brasil Mulher (1975-1980) e o Nós, Mulheres (1976-1978). Neste trabalho, elas destacam a história de diversas mulheres que propuseram pensar uma nova maneira de fazer política, politizando o cotidiano, lutando por liberdades democráticas, pela Anistia e pelo fim da ditadura. Ao narrar um pouco de sua trajetória, Amelinha Teles ${ }^{6}$ lembra e realça a complexa relação das mulheres, feministas e militantes com os líderes das organizações de esquerda. Ela nos conta que os homens desconfiavam da presença das mulheres nesses espaços, e, além disso, ela evidencia que para a esquerda o feminismo era visto como um desvio pequeno burguês e para a direita as feministas eram mulheres sem moral que tinham por objetivo acabar com a "família tradicional brasileira".

Em vista disso, podemos questionar: por que a maioria das narrativas sobre os chamados "heróis da resistência" focalizam predominantemente os homens? Para a

\footnotetext{
4 SUGIMOTO, Luiz. Mulheres na linha de frente. Jornal Unicamp, Campinas, no 592, março-abril de 2014. Disponível em: <http://www.unicamp.br/unicamp/ju/592/mulheres-na-linha-de-frente> . Acesso em: 1 jul. 2016.

${ }^{5}$ Ver também: MORAES, Maria Lygia Quartim de (Org.). Memórias da repressão militar e da resistência política. Campinas, IFCH-Unicamp, 2009; ROSA, Susel Oliveira. Mulheres, ditaduras e memórias: não imagine que precise ser triste para ser militante. São Paulo: Intermeios, 2013; BORDIN, Laura Leal \& LORIANNY, Suelen. Sem Liberdade, Eu Não Vivo - Mulheres Que Não Se Calaram na Ditadura. Curitiba, PR - Editora Compactos, 2013.

${ }^{6}$ OLIVEIRA, Samir. Amelinha Teles e a incansável luta contra o machismo: dos anos 1960 aos dias de hoje. SUL21. Disponível em: <http://www.sul21.com.br/jornal/amelinha-teles-e-incansavel-luta-contra-o-machismodos-anos-1960-aos-dias-de-hoje/>. Acesso em: 1 jul. 2016.
} 
Ditadura civil-militar no Brasil e a ordem de gênero: masculinidades e feminilidades vigiadas

historiadora Cristina Wolff, ao lembrar a fala de uma entrevistada uruguaia, ela diz que isso ocorre por que: "'ao sair da prisão, os homens foram dar entrevista coletiva à imprensa, e as mulheres foram correndo para suas casas e suas famílias" ${ }^{7}$, reforçando, em grande medida, as posições normativas de gênero, mulheres restritas ao espaço doméstico, ao cuidado da casa e dos filhos e aos homens, o espaço público, arena da chamada grande política.

Essa polarização entre direta-esquerda, burguesia-proletariado, dominava e orientava as disputas políticas no espaço público, pode se dizer que eram a tópica das episteme hegemônica, ainda sob um contexto de Guerra Fria e de Revolução Cubana, que se percebia numa luta do "nós" conta "eles", comunista de um lado, e neoliberais, conservadores, autoritários e imperialistas do outro. E no meio disso tudo, temos as feministas e os militantes do movimento homossexual buscando novas estratégias de fazer política para além dessa visão binaria de mundo. Semelhantemente, essa visão diádica sobre as feministas também foi atribuída às homossexualidades. Como bem aponta James Green, a relação entre homossexualidade com a direita e a esquerda era envolta em mitos. Os grupos à direita, concebiam a homossexualidade como degenerescência, subversão, em último grau, uma expressão máxima da dissolução da ordem social protagonizadas por grupos comunistas. Entre à esquerda, muitos militantes concebiam "a homossexualidade como um desvio burguês ou uma doença" (GREEN, 2014, p. 191).

Entre os militantes integrantes do Somos (primeira organização do movimento homossexual fundada em 1978), em que muitos eram de esquerda, defendia-se apenas o combate à discriminação de gays e lésbicas, com raras discussões sobre as travestis, e outros defendiam "a necessidade de priorizar a luta contra a ditadura" (GREEN, 2014, p. 190-191). Assim, a luta percebida como "específica" se contrapunha "a luta maior", ou seja, o que importava era a luta da classe operária contra o sistema capitalista, colocando em segundo plano as lutas dos movimentos de mulheres, negros e homossexuais.

No artigo Quem é o macho que quer me matar? James Green nos oferece algumas pistas sobre a complexa e conflituosa relação entre os militantes de esquerda em as homossexualidades. De modo geral, o autor observa que:

Dezenas de ex-revolucionários brasileiros que aderiram à luta armada, na década de 1960 e início de 1970, escreveram sobre suas experiências nesse período. Mas resta um silêncio sobre a sexualidade, especialmente a homossexualidade, entre quase todos os autores dessas obras (GREEN, 2012, p. 63).

Com exceção da obra de Herbert Daniel Passagem para o Próximo Sonho, em que o autor, segundo Green, focaliza a própria experiência como "um guerrilheiro urbano e de sua homossexualidade reprimida" (GREEN, 2012, p. 63), percebe-se um silenciamentos em torno

\footnotetext{
${ }^{7}$ WOLFF, Cristina Scheibe. O Golpe de 1964 e a luta feminina por espaço na memória. Entrevista especial com Cristina Wolff. Unisinos. Disponível em: <http://www.ihu.unisinos.br/entrevistas/529997-a-luta-feminina-porespaco-na-memoria>. Acesso em: 1 jul. 2016.
} 
das homossexualidades. Não por acaso, um dos desafios evidenciados por James Green é a indisponibilidade de fontes adicionais, como entrevistas e relatos de ex-militantes, no intuito de produzir uma "história social e cultural mais complexa e completa sobre a oposição" (GREEN, 2012, p. 64) à ditadura civil-militar.

Por conseguinte, Green sugere e defende a necessidade de explorarmos as "contradições internas da esquerda revolucionária que defendia a liberdade, a libertação e uma transformação radical da sociedade, mas que marginalizava homens ou mulheres que não seguiam gêneros e comportamentos sexuais normativos" (GREEN, 2012, p. 64). O autor salienta que os defensores da chamada esquerda revolucionária acreditavam que os indivíduos, principalmente jovens, que não se aliavam a luta armada, eram alienados. E os militantes que tinham abandonado suas organizações eram considerados traidores da causa. Assim, Green identifica pelo menos cinco "enquadramentos ideológicos paralelos e complementares" que circulavam e formatavam a percepção da esquerda brasileira em 1960 em relação às homossexualidades:

O primeiro, ligava a homossexualidade ao comportamento burguês e, portanto, à contrarrevolução. O segundo, concordava com conceitos médicos e psiquiátricos, a partir dos quais a homossexualidade era uma degeneração física e emocional. Outra atitude, embora provavelmente inconsciente, se baseava nos ensinamentos católicos tradicionais que consideravam a homossexualidade uma abominação moral. Sentimento anti-imperialista associado ao comportamento homossexual e críticas à homofobia com influências alheias e estrangeiras (leia-se: EUA) (GREEN, 2012, p. 71).

Com base nessas concepções negativas e excludentes se constituiu um código de hierarquização social entre jovens de classe média, perfil da maioria dos membros dos grupos da luta armada, disputando "quem era mais puro, mais revolucionário e quem não alcançava os padrões" (GREEN, 2012, p. 73) de uma suposta masculinidade revolucionária condensada na figura histórica de Che Guevara, defensor de um "novo homem", caracterizado pela força, dominação, virilidade e agressividade que não abria espaço para homossexualidade, percebida até então como um perigo à masculinidade, levando a um suposto efeminamento e que "tinha só um objetivo em mente que era o sacrifício pela causa, adiando prazeres mundanos do momento em busca de um futuro socialista glorioso" (GREEN, 2012, p. 78). Isso tudo nos mostra como a lógica masculina, machista e masculinizante de pensar a sociedade afetava a tudo e a todos. E é no fluxo dessa atmosfera política, ideológica, social e cultural que precisamos observar e investigar as práticas de possíveis resistências às normas de gênero vigente no período e a complexa relação dos sujeitos homossexuais com a ditadura.

Dissidências de gênero e sexualidade na ditadura 
Se entendermos que sexualidade não é um sinônimo de relações sexuais, logo, falar de sexualidade é atentar para um constructo que envolve "desejo, afeto, autocompreensão e até a imagem que os outros têm de nós" (MISKOLCl, 2012, p. 39), ou seja, somos marcados, atravessados e constituídos pelas normas e pela experiência de sujeito de gênero, pois estamos todos no rio da história. Assim, historicizar as concepções de masculinidade e feminilidade é um modo de compreender como dada sociedade concebe o que é entendido como normal e anormal no campo das identidades. Como já nos disse Foucault, nas relações de poder: "A sexualidade não é o elemento mais rígido, mas um dos dotados da maior instrumentalidade: utilizável no maior número de manobras, e podendo servir de ponto de apoio, de articulação às mais variadas estratégias" (1988, p. 114).

Assim, entendo que é preciso focalizar quais as estratégias do poder forjadas para enquadrar, normatizar, normalizar e heterossexualizar os sujeitos de gênero. No caso da ditadura, a repressão e a censura podem ser entendidas como algumas das estratégias e táticas utilizadas para tentar controlar e homogeneizar a sociedade em torno de um projeto de Estado-Nação, sustentado por um ideal de família heterossexual e reprodutiva - não só no plano biológico -, mas também na promoção e manutenção de valores conservadores.

James Green recorda que no início dos anos 70 as disputas de censura "estavam circunscritas em larga medida às expressões literárias e artísticas que os militares encaravam com um desafio direto à política do regime ou à moralidade pública" (GREEN, 2000, p. 39). Todavia, a censura praticada pelo Sistema Nacional de Informações (SNI) não era um todo homogêneo, ela tinha suas singularidades, o que estava em jogo era uma concepção de sociedade como uma unidade orgânica, alicerçada na assimetria e complementaridade entre homem e mulher, concebidos como mantenedores da ordem familiar heterossexual e consequentemente de toda a sociedade. Deste modo, para os militares o Estado encarnava a racionalidade e caberia às instituições organizar e controlar as diferentes esferas da vida social, objetivando o desenvolvimento econômico. Assim, "toda contestação ao Estado é uma ameaça a seus fundamentos" (ORTIZ, 2014, p. 120). De acordo com o historiador Carlos Fico, a censura já vinha sendo praticada no Brasil antes mesmo do regime militar, em suas palavras:

Não se pode falar propriamente no "estabelecimento" da censura durante o regime militar, porque ela nunca deixou de existir no Brasil. Livros, jornais, teatro, músicas e cinema sempre foram atividades visadas pelos mandantes do momento e, muitas vezes, tratados como simples rotina policial, pois as prerrogativas da censura de diversões públicas sempre foram dadas aos governos de maneira explícita, legalizadamente. Ademais, instrumentos reguladores-como "Leis de imprensa", "classificações etárias" (para diversões públicas) e proibições de "atentados à moral e aos bons costumes" - frequentemente possibilitaram mecanismos censórios que contavam, além disso, com o benefício da legitimação que largas parcelas da sociedade lhes conferem, já que os consideravam "naturais". Assim, para a ditadura militar, tratava-se mais de uma adequação, não de uma criação (FICO, 2003, p. 187-188, grifos meus). 
Por isso, para o autor, os militares aperfeiçoaram as práticas repressoras, sobre temas como a nudez e a homossexualidade, que já vinham sendo praticadas no Brasil em governos anteriores, pois grande parte de setores da sociedade pertencente às camadas média e alta temiam a expansão de novos valores, - como a liberalização sexual-, que solapassem a moral católica conservadora até então predominante. Porém, considero necessário desconfiar dessa ideia de que somente os membros das denominadas classes média e alta eram conservadores. Não podemos desconsiderar as pessoas comuns, os trabalhadores, as senhoras religiosas, etc., que possivelmente seguiam a sua vida de modo regular, casando os filhos, indo à igreja aos domingos, e certamente não eram mais "progressistas" ou tolerantes com os novos sujeitos políticos que disputavam legitimidade no espaço público. Como aponta Douglas Marcelino (2011), o medo de "corromper a juventude" mobilizava algumas entidades católicas, compostas por pessoas ditas "comuns", como o Movimento por um Mundo Cristão (MMC) e a União Feminina (UCF) que enviavam cartas para delegados da DCDP, no intuito de denunciar o que consideravam um perigo a ordem moral e social. Assim sendo, a partir do Al-5, que foi um dos instrumentos legais perpetrados pela ditadura civil-militar para conter aqueles considerados "inimigos da moral e dos bons costumes", os principais alvos da censura foram, além da imprensa, as atividades artísticas como o "teatro, o cinema, a tv, o circo, os bailes musicais [e] as apresentações de cantores em casas noturnas" (FICO, 2003, p. 189), ou seja, todas as manifestações que em alguma medida apresentassem uma 'ameaça' ao projeto de homogeneização e manutenção da noção de masculinidade e feminilidade vigente na sociedade.

Benjamim Cowan, a partir da análise de documentos oficiais da repressão como relatórios do SNI (Sistema Nacional de informações) e da ESG (Escola Superior de Guerra), aponta como os ideólogos conservadores e planejadores do regime de segurança nacional dos anos 1960 -1980, recorreram a uma tradição presente desde o Integralismo no Brasil, anos 1930, que concebia a homossexualidade - principalmente a masculina, seja ela pública ou privada, como uma subversão inimiga. Esses ideólogos compreendiam a homossexualidade masculina "como uma prática de generativa, furtiva e de efeminados, que elas vaga e variavelmente associaram com subversão comunista e vulnerabilidade política". ${ }^{8}$ Assim, em fins dos anos 1970, "policiais retinham interpretações antigas, médico-legais, do desejo homossexual", associando-a com ameaças ao estado, à sociedade e à segurança nacional, que levariam a uma suposta dissolução social. O grande temor desses ideólogos era a concepção de uma suposta perda de virilidade, ou seja, um efeminamento provocado pelo 'desvio' homossexual. $\mathrm{O}$ autor assevera ainda que a

Homossexualidade nunca chegou a ser a razão principal pela qual as pessoas foram presas, torturadas e sujeitas aos abusos dos direitos humanos e civis - mas formou parte de um conjunto de ansiedades sobre a

\footnotetext{
8 COWAN, Benjamin. Homossexualidade, ideologia e "subversão" no regime militar. In: GREEN, James; QUINALHA, James (orgs.). Ditadura e homossexualidades: repressão, resistência e a busca da verdade. São Carlos: EduFSCar, 2014, p. 32.
} 
Ditadura civil-militar no Brasil e a ordem de gênero: masculinidades e feminilidades vigiadas

ameaça, vaga e supostamente difusa, da subversão (COWAN, 2014, p. 36).

Essa concepção se fez presente nos dossiês elaborados contra os 'inimigos do regime', praticado pela Polícia dos Costumes, por exemplo. De modo geral, as forças de segurança - SNI, consideravam a ascensão do Movimento Gay como uma conspiração do que eles denominavam vulgarmente de $\mathrm{MCl}$ - Movimento Comunista Internacional. A expressão, Movimento homossexual, por sua vez, segundo Green, era um termo da época utilizado para se referir aos grupos organizados por gays e lésbicas.

Luiz Morando (2014) evidencia a ação conjunta de Delegacias Especializadas de Jogos, de Costumes, de Repressão À Vadiagem, de Menores e de Repressão ao Contrabando ao analisar a repressão impetrada a gays e travestis nos espaços de homossociabilidade (bares, restaurantes, etc.) em Belo Horizonte (1963-1969), denunciando a articulação entre o poder judiciário e as forças policiais na manutenção de uma suposta ordem moral e social. Com um olhar acurado sobre os discursos jurídicos, Rita Colaço Rodrigues elucida que em nome da "utopia autoritária" estabeleceu-se leis como o Código Brasileiro de Telecomunicações e a Lei de Imprensa, ambos de 1967; a Lei de Segurança Nacional, de 1969 e o Decreto-Lei 477, que previa "a expulsão de professores, alunos e funcionários de estabelecimentos de ensino públicos e particulares, entre outras motivações, pela prática de atos atentatórios à moral e aos bons costumes; o decreto da censura prévia, em 1970" (RODRIGUES, 2014, p. 209).

Esse conjunto de valores normativos quanto à sexualidade incidiu nas práticas de censura sobre jornais como o Lampião da Esquina (o primeiro periódico produzido por e para homossexuais a circular no âmbito nacional entre os anos de 1978-1981) que buscava falar da homossexualidade de maneira positiva, contestando os estigmas recorrentemente atribuídos ao tema em jornais de grande circulação, reforçando assim o caráter patológico e "anormal" dos homossexuais assim como a censura a alguns personagens televisivos ${ }^{9}$ considerados uma ameaça à juventude.

Rita Colaço Rodrigues sugere que a censura televisiva ganhou força nos anos 1970 tendo como um dos seus fundamentos "o controle daquilo que, para os detentores do poder e setores da população, pudesse violar uma suposta moral da família brasileira" (RODRIGUES, 2014, p. 209). É nesse sentido que personalidades da época como Clóvis Bornay (museólogo e tradicional participante dos concursos de fantasias de carnaval), Denner Pamplona Abreu e Clodovil Hernandez (famosos costureiros de mulheres da elite econômica e cultural) e o cabelereiro Antonio Carlos, foram proibidos de se apresentarem na tv sob a acusação de que "seus maneirismos, sua falta de masculinidade [leia-se, virilidade], são prejudiciais à formação moral da infância e da juventude" (RODRIGUES, 2014, p. 213). Temas como homossexualidade e os homossexuais, questão racial, prostituição, tortura e prisões arbitrárias, segundo Colaço, eram proibidos pelo aparato censório do regime. Enfim,

\footnotetext{
${ }^{9}$ Sobre a presença de personagens LGBTs na tv consultar: RIBEIRO, Irineu Ramos. A TV no armário: a identidade gay nos programas e telejornais brasileiros. São Paulo: GLS, 2010; NASCIMENTO, Fernanda. Bicha (nem tão má): LGBTs em telenovelas. Rio de Janeiro: Multifoco, 2015.
} 
de modo geral, a repressão impetrada pelos militares - a partir do Al-5, com apoio de setores da sociedade civil, retardou o efetivo surgimento do movimento homossexual no Brasil, como sugere James Green ${ }^{10}$.

Colaço entende que "o imaginário de país presente entre os militares era o de uma nação uniforme, moldada em torno de valores cívicos e patrióticos autoritariamente impostos" (RODRIGUES, 2014, p. 209-210). Tudo que não se enquadrava nesse projeto de poder era considerado "subversivo", um atentado contra a "moral e os bons costumes". Tal projeto conservador de sociedade, segundo Rita Colaço, "era a expressão viva da concepção de mundo de parte considerável da população brasileira" (Idem:210), manifesta através das marchas da Família com Deus pela Liberdade e das constantes cartas em tom de denúncia enviada de todo o país aos órgãos de censura pela Liga das Senhoras Católicas. Um dos casos mais notórios e o de Denner Pamplona, ele chegou a apresentar um programa "Denner é um Luxo" na TV Itacolomi de Minas Gerais, alcançando cerca de $73 \%$ de audiência local, como aponta Colaço. Ao mesmo tempo, pedidos foram encaminhados à Polícia Federal, pela Liga das acusando-o de "negação da masculinidade", devido aos seus "trejeitos" nada másculos. Deste modo, Colaço assevera que esses personagens foram proibidos de se apresentarem na tv sob a acusação de que "seus maneirismos, sua falta de masculinidade, são prejudiciais à formação moral da infância e da juventude" (RODRIGUES, 2014, p. 213).

Como sublinha James Green, homossexuais, lésbicas e travestis só eram tolerados, no mais, eram os alvos prediletos do conservadorismo vigente. Uma verdadeira "caça as bruxas", um pânico moral instituído em torno dos sujeitos que não se enquadravam na heteronorma. Logo:

O perigo, então, não era só a feminilidade pública, mas a ideia de que as várias encarnações da homossexualidade pública, das bichas e dos cabeleireiros na televisão até a nova imprensa gay, identificada como tal, aliciariam as pessoas à prática da homossexualidade ou - pior ainda tornarem-se homossexuais auto identificados e denominados (COWAN, 2014, p. 37).

Por fim, não podemos nos esquecer da histórica personagem Leila Diniz ${ }^{11}$, que na época ficou marcada como uma ameaça ao modelo heteronormativo de família por falar publicamente dos seus amores e afetos. Para os militares, ela era um péssimo exemplo às jovens solteiras, por fazer apologia ao sexo fora do casamento. Para grupos feministas, ela representava uma postura vulgar por defender a liberdade sexual e para grupos de esquerda, ela era vista como alienada. Sua entrevista ao 0 Pasquim, ${ }^{12}$ em 15 de novembro de 1969,

\footnotetext{
10 MERLINO, Tatiana. Historiador brasilianista fala sobre a perseguição aos grupos LGBT durante a ditadura, inclusive dentro da esquerda. Carta Capital, 29/04/2014. Disponível em: <http://www.cartacapital.com.br/sociedade/o-ai-5-atrasou-por-anos-o-movimento-gay-no-brasil-5222.html>. Acesso em: 1 jul. 2016.

${ }^{11}$ SANTOS, Joaquim Ferreira dos. LEILA DINIZ: uma revolução na praia. São Paulo, Companhia das Letras. 2008; GOLDENBERG, Mirian. Toda mulher é meio Leila Diniz. 2a ed. Rio de Janeiro: Edições Bestbolso, 2008.

${ }^{12}$ Entrevista completa ao O Pasquim. Disponível em: <http://www.omartelo.com/omartelo23/musas.html\#alto
} 
incomodou os censores da ditadura. Na longa entrevista concedida ao semanário Leila Diniz chegou a dizer cerca de 71 palavrões, falou dos seus amores, da preferência por homens casados e de ter perdido a virgindade na passagem dos 15 aos 16 anos, o que fez com que a ditadura oficializasse a censura prévia aos periódicos que fora denominada de - Lei Leila Diniz. Após essa longa entrevista, foi punida moralmente, perdendo o emprego de atriz em importantes canais de tv como a Rede Globo, Excelsior e Tupi e tendo que viver de pequenos trabalhos. Angélica Müller sublinha que Leila Diniz foi "o signo da liberdade feminina potencializada pelos valores viris de independência e autoconfiança, motivo para aflorar o machismo dos mais conservadores" (MULLER, 2013, p. 318).

\section{Conclusão}

A partir do que foi exposto acima podemos perceber que machismo, sexismo e homofobia existiam tanto à direita e à esquerda do espectro político vigente naquele período. Também é perceptível que essas pautas e demandas em torno do gênero, da sexualidade e da corporeidade, eram bombardeadas de ambos os lados, não sendo reconhecidas, a princípio, como demandas legítimas desses novos sujeitos políticos. Assim, podemos desconfiar e questionar de algumas narrativas que tentam associar uma certa e histórica concepção de democracia e igualdade como uma bandeira das organizações de esquerda "desde sempre". Homens e mulheres não se enquadravam na posição de gênero dominante foram censurados, vigiados, denunciados e punidos moralmente por expressarem uma feminilidade e masculinidade considerada subversiva.

Ao mesmo tempo, com suas práticas dissidentes para à época, ajudavam a desnaturalizar as históricas concepções e atribuições de gênero percebidas, até então, como naturais para homens e mulheres. Com efeito, se entendermos que as noções de masculinidade e feminilidade são constructos social e culturalmente forjados, rizomáticos, relacionais, interdependentes e de múltipla definição. Podemos não só complexificar e desconfiar do que está posto, como também evidenciar o caráter histórico, datado e político do gênero. Esse é o desafio que está posto, cabe a cada historiador e historiadora aceitá-lo, ou não.

>. Acesso em: 30/08/2015. 


\section{Referências}

AARÃO REIS, Daniel. Ditadura e democracia no Brasil: do golpe de 1964 à Constituição de 1988. Rio de Janeiro: Zahar, 2014.

ALBUQUERQUE JÚNIOR, D.M. História a arte de inventar o passado. Ensaios de teoria da história-Bauru, SP: Edusc, 2007.

ALONSO, Angela; DOLHNIKOFF, Miriam. (Orgs). 1964: do golpe a democracia. São Paulo, Editora HEDRA, 2015.

AQUINO, Maria Aparecida de. Censura, Imprensa e Estado autoritário (1968-1978): o exercício cotidiano da dominação e da resistência: O Estado de São Paulo e Movimento/ Bauru: EDUSC, 1999.

BORDIN, Laura Leal; LORIANNY, Suelen. Sem Liberdade, Eu Não Vivo - Mulheres Que Não Se Calaram na Ditadura. Curitiba: Editora Compactos, 2013.

BUTLER, Judith. Problemas de gênero: feminismo e subversão da identidade. Tradução de Renato Aguiar. Rio de Janeiro: Civilização Brasileira, 2013.

CABRAL, Jacqueline Ribeiro. Imorais e subversivos: censura a LGBTs durante a ditadura militar no Brasil. Revista Periódicus, v. 1, p. 127-150, 2015.

COELHO, Vinicius. Lampião da Esquina: Porta voz dos homossexuais (1978-1981). RJ: Editora Multifoco, 2014.

COLLING, Ana Maria. A resistência da mulher na ditadura militar no Brasil. RJ: Rosa dos Tempos, 1997.

. 50 anos da Ditadura no Brasil: questões feministas e de gênero. OPSIS, Catalão, v. 15, n. 2, p. 370-383, 2015.

COWAN, Benjamin. Homossexualidade, ideologia e "subversão" no regime militar. In: GREEN, James; QUINALHA, James (Orgs.). Ditadura e homossexualidades: repressão, resistência e a busca da verdade. São Carlos: EduFSCar, 2014, p. 27-52.

DREIFUSS, René Armand. 1964: a Conquista do Estado Ação Política, Poder e Golpe de Classe. Petrópolis, VOZES, 1981.

FICO, Carlos. Espionagem, polícia política, censura e propaganda: os pilares básicos da 
repressão. In: FERREIRA, Jorge; DELGADO, Lucilia De Almeida Neves. (Orgs.). O tempo da ditadura: regime militar e movimentos sociais em fins do século XX. RJ: Civilização Brasileira, 2003, p. 167-205.

. Versões e controvérsias sobre 1964 e a ditadura militar. Revista Brasileira de História. São Paulo, v. 24, no 47, p. 29-60, 2004.

- História do Tempo Presente, eventos traumáticos e documentos sensíveis - o caso brasileiro. VARIA HISTORIA, Belo Horizonte, v. 28, n. 47, p. 45-59, jan/jun, 2012.

- Ditadura Militar: mais do que algozes e vítimas. A perspectiva de Carlos Fico. [Entrevista realizada em 24 de julho, 2013]. Revista Tempo e Argumento, Florianópolis, v. 5, n.10, jul./dez., p. 464-483, 2013. Entrevistadores: Silvia Maria Fávero Arend, Rafael Rosa Hagemeyer e Reinaldo Lindolfo Lohn.

- Violência, trauma e frustração no Brasil e na Argentina: o papel do historiador, Topoi, Rio de Janeiro, v. 14, n. 27, p. 239-261, jul./dez. $2013 a$.

. O Golpe de 1964: momentos decisivos. Rio de Janeiro: Editora FGV, 2014.

FISCHER, Rosa Maria Bueno. Trabalhar com Foucault - arqueologia de uma paixão. Belo Horizonte: Autêntica Editora, 2012.

FOUCAULT, Michel. A História da Sexualidade I: A vontade de saber. 21a reimpressão. Rio de Janeiro: Edições Graal, 1988.

GREEN, James. "Quem é o macho que quer me matar?": Homossexualidade masculina, masculinidade revolucionária e luta armada brasileira dos anos 1960 e 1970, 2012. Disponível em: <http://www.corteidh.or.cr/tablas/r33222.pdf>

. O grupo somos, a esquerda e a resistência à ditadura. In: GREEN, James; QUINALHA, James (orgs.). Ditadura e homossexualidades: repressão, resistência e a busca da verdade. São Carlos: EduFSCar, 2014, p. 177-200.

GREEN, James Naylor. Além do carnaval. A homossexualidade masculina no Brasil do século XX. São Paulo: Editora UNESP, 2000.

GREEN, James; POLITO, Ronald. Frescos trópicos: fontes sobre a homossexualidade masculina no Brasil (1870-1980). Rio de Janeiro: Editora José Olympo, 2006.

GREEN, James; QUINALHA, James (Orgs.). Ditadura e homossexualidades: repressão, resistência e a busca da verdade. São Carlos: EduFSCar, 2014.

JUNIOR, Ottoni Fernandes. O baú do guerrilheiro: memórias da luta armada urbana no Brasil. Editora Record, 2004. 
MALERBA, Jurandir. A História na América Latina: ensaio de crítica historiográfica. Rio de Janeiro: Editora FGV, 2009.

MARCELINO, Douglas Attila. Subversivos e Pornográficos. Censura de livros e diversões públicas nos anos 1970. Rio de Janeiro: Arquivo Nacional, 2011.

MISKOLCI, Richard. Teoria Queer: um aprendizado pelas diferenças. Belo Horizonte: Autêntica Editora, 2012.

MORAES, Maria Lygia Quartim de (Org.). Memórias da repressão militar e da resistência política. Campinas: IFCH-Unicamp, 2009.

MORANDO, Luiz. Por baixo dos panos: repressão a gays e travestis em Belo Horizonte (19631969). In: GREEN, James; QUINALHA, James (Orgs.). Ditadura e homossexualidades: repressão, resistência e a busca da verdade. São Carlos: EduFSCar, 2014, p. 53-81.

MÜLLER, Angélica. Não se nasce viril, torna-se: juventude e virilidade nos "anos 1968". In: DEL PRIORE, Mary; AMANTINO, Márcia. (Org.). História dos Homens no Brasil. São Paulo: Unesp, 2013, p. 299-333.

GIANORDOLI NASCIMENTO, Ingrid Faria; Trindade, Zeidi Araújo; Santos, Maria de Fátima de Souza. Mulheres e militância: encontros e confrontos durante a ditadura militar. Belo Horizonte: UFMG, 2012.

NAPOLITANO, Marcos. Coração civil: arte, resistência e lutas culturais durante o regime militar brasileiro (1964-1980). Tese de Livre-Docência em História, USP, 2011.

ORTIZ, Renato. Revisitando o tempo dos militares. In: REIS, Daniel Aarão; RIDENTI, Marcelo \& MOTTA, Rodrigo P. Sá (Orgs.). A ditadura que mudou o Brasil: 50 anos do golpe de 1964. Rio de Janeiro: Zahar, 2014, p.112-127.

PADRÓS, Enrique Serra. Repressão e violência: segurança nacional e terror nas ditaduras latino-americanas. In: FICO, Carlos et al (Org). Ditadura e Democracia na América Latina: balanço e perspectivas. Rio de Janeiro: Editora FGV, 2008, p.143-178.

PEDRO, Joana. Traduzindo o debate: o uso da categoria gênero na pesquisa histórica. História (São Paulo), v. 24, p. 77-98, 2005.

- Relações de gênero como categoria transversal na historiografia contemporânea. Topoi, v. 12, n. 22, jan./jun., p. 270-283, 2011.

PEDRO, Joana Maria; WOLFF, Cristina Scheibe. As dores e as delícias de lembrar a ditadura no Brasil: uma questão de gênero. História Unisinos, v. 15, p. 398-405, 2011.

PROST, Antoine. Doze lições Sobre a História. Belo Horizonte: Autêntica Editora, 2008. 
82 Ditadura civil-militar no Brasil e a ordem de gênero:

masculinidades e feminilidades vigiadas

RAGO, Margareth. Descobrindo historicamente o gênero. Cadernos Pagu (11), p. 89-98, 1998.

. Feminizar é preciso: por uma cultura filógina. São Paulo Perspec. [online]. 2001. vol.15, n.3, p. 53-66. ISSN 0102-8839. Disponível em: <http://dx.doi.org/10.1590/S0102$88392001000300009>$.

Epistemologia feminista, gênero e história. In: GROSSI, Miriam Pillar. PEDRO, Joana M. Masculino, feminino, plural, gênero na interdisciplinaridade. SC- Editora mulheres; p.21-41, 2006.

. A aventura de contar-se: feminismos, escrita de si e invenções da subjetividade, Campinas: Editora da Unicamp, 2013.

. O efeito-Foucault na historiografia brasileira. Tempo Social; USP, São Paulo, 7(1-2): 6782, outubro de 1995.

RIDENTI, MARCELO. Resistência e mistificação da resistência armada contra a ditadura: armadilhas para os pesquisadores. In: REIS, Daniel Aarão; RIDENTI, Marcelo \& MOTTA, Rodrigo P. Sá (Orgs.). O golpe e a ditadura militar - 40 anos depois (1964- 2004). Bauru: EdUSC, 2004. p.53-65.

As oposições à ditadura: resistência e integração. In: REIS, Daniel Aarão; RIDENTI, Marcelo \& MOTTA, Rodrigo P. Sá (orgs.). A ditadura que mudou o Brasil: 50 anos do golpe de 1964.1a.ed. Rio de Janeiro: Zahar, 2014, p.30-47.

RODRIGUES, Rita de Cássia Colaço. De Denner à Chrysóstomo, a Repressão Invisibilizada: As Homossexualidades na Ditadura In: James Green e Renan Quinalha. (Org.). Ditadura e homossexualidades: repressão, resistência e a busca da verdade. São Carlos: EduFSCar, 2014, p. 201-244.

ROSA, Susel Oliveira. Mulheres, ditaduras e memórias: não imagine que precise ser triste para ser militante. São Paulo: Intermeios, 2013.

SALES, Jean Rodrigues. Guerrilha e revolução: a luta armada contra a ditadura militar no Brasil. Rio de Janeiro: Lamparina, 2015.

- A luta armada contra a ditadura militar: a esquerda brasileira e a influência da revolução cubana. São Paulo: Fundação Perseu Abramo, 2007.

SARTI, Cynthia A. O feminismo brasileiro desde os anos 1970: revisitando uma trajetória. Estudos Feministas, Florianópolis, 12(2): p. 35-50, maio-agosto, 2004.

. Feminismo e contexto: lições do caso brasileiro. Cadernos Pagu (16), p. 31-48, 2001. 
SILVA, Robson Pereira da. Um verme passeia na lua cheia: performance e cenicidade audiovisual em Ney Matogrosso na construção de um fazer artístico na década de 1970. Revista Eletrônica Trilhas da História, v. 3, p. 138-156, 2013.

A Contracultura no Brasil: Secos \& Molhados e a Indústria Cultural na Década de 1970. In: Anais do VI Simpósio Nacional de História Cultural Escritas da História: Ver - Sentir Narrar. Teresina, Universidade Federal do Piauí, UFPI, 2012.

SILVA, Vinícius Rangel Bertho da. O DOCE \& O AMARGO DO SECOS \& MOLHADOS: poesia, estética e política na música popular brasileira. Dissertação (mestrado), Niterói: UFF, 2007.

TELES, Amelinha; LEITE, Rosalina Santa Cruz. Da guerrilha à imprensa feminista: a construção do feminismo pós-luta armada no Brasil (1975-1980). São Paulo: Intermeios, 2013.

TREVISAN, João Silvério: Devassos no paraíso - A homossexualidade no Brasil, da colônia à atualidade -Ed. revisada e ampliada- 8a Ed. Rio de Janeiro: Record, 2011.

WELZER-LANG, Daniel. Os homens e o masculino numa perspectiva de relações sociais de sexo. In: SCHPUN, Mônica Raisa (org.). Masculinidades. São Paulo: Boitempo Editorial; Santa Cruz do Sul: Edunisc, 2004, p. 107-128.

ZACHARIADHES, Grimaldo Carneiro. 1964: 50 anos depois: a ditadura em debate. Aracajú: EDISE, 2015. 